\title{
shRNA-induced silencing of Ras-related C3 botulinum toxin substrate 1 inhibits the proliferation of colon cancer cells through upregulation of BAD and downregulation of cyclin D1
}

\author{
YOU-SHENG HUANG ${ }^{1}$, NA JIE ${ }^{1}$, YI-XIN ZHANG ${ }^{1}$, KE-JIAN ZOU ${ }^{2}$ and YANG WENG ${ }^{1}$ \\ ${ }^{1}$ Department of Pathology, The First Affiliated Hospital of Hainan Medical University, Hainan Medical University, \\ Haikou, Hainan 571101; ${ }^{2}$ Department of Gastrointestinal Surgery, \\ Hainan Provincial People's Hospital, Haikou, Hainan 570311, P.R. China
}

Received October 27, 2016; Accepted December 13, 2017

DOI: $10.3892 /$ ijmm.2017.3345

\begin{abstract}
Ras-related C3 botulinum toxin substrate 1 (RAC1) is a member of the Rho family of small GTPases. Recent studies have reported that RAC1 serves an important role in colon cancer cell proliferation. The present study aimed to investigate the effects of $R A C l$ knockdown on cell proliferation, cell cycle progression and apoptosis of colon cancer cells. Lentivirus-mediated short hairpin RNA (shRNA) was used to knockdown $R A C l$ expression in colon cancer cell lines, and cell proliferation, apoptosis, cell cycle progression were evaluated by MTT assays and flow cytometry. The differences in mRNAs expression were identified between RAC1-knockdown cells and control cells using a mRNA microarray, following which quantitative PCR (qPCR) and western blot were employed to confirm the results of the mRNA microarray. The proliferative ability of colon cancer cells was significantly decreased following $R A C l$ knockdown, and $R A C l$ knockdown increased the apoptotic rate and enhanced cell cycle arrest at $G_{1}$ phase in colon cancer cells. In addition, $>1,200$ known genes were demonstrated to be involved in $\mathrm{RACl}$-associated tumorigenic functions in SW620 colon cancer cells, as determined by gene chip analysis; these genes were associated with cell proliferation, cell cycle, apoptosis and metastasis. Furthermore, western blot analysis indicated that cyclin D1 was downregulated, whereas B-cell lymphoma 2-associated agonist of cell death (BAD) was upregulated following $R A C 1$ knockdown in colon cancer cells. In conclusion, $R A C l$ silencing may suppress the proliferation of colon cancer cells by inducing apoptosis and cell cycle arrest. In addition, a large number of genes were revealed to be involved in the process, including $B A D$, which was upregulated and cyclin D1, which was downregulated.
\end{abstract}

Correspondence to: Professor You-Sheng Huang, Department of Pathology, The First Affiliated Hospital of Hainan Medical University, 31 Long Hua Road, Haikou, Hainan 571101, P.R. China E-mail: hys768811@163.com

Key words: colon cancer, Ras-related $\mathrm{C} 3$ botulinum toxin substrate 1, microarray, RNA interference, bioinformatics
Further studies on these differentially expressed genes may provide a better understanding of the potential roles of RAC1 in colon carcinogenesis.

\section{Introduction}

Colon cancer is one of the most common malignant tumors worldwide. In China, colon cancer is the fifth most common type of cancer, and metastasis and recurrence of colon cancer are the leading causes of mortality in most patients (1). At present, surgical resection is the first-line treatment for patients with colon cancer $(1,2)$; however, surgical treatment is difficult to perform in patients with recurrent cancer and metastasis (2). Numerous studies have reported that molecular targeted therapy may further improve the survival of patients with metastatic colon cancer (2-4). For example, treatment with cetuximab, an anti-vascular endothelial grow th factor receptor antibody, alongside standard chemotherapy is approved for first-line therapy in patients with K-ras mutations, and for second-line therapy in patients with metastatic colon cancer harboring wild-type K-ras $(3,5)$. Although numerous molecular targets have been identified for individual-specific, targeted therapies in patients with colon cancer, the mechanisms underlying these therapies remain unclear, few agents are available, and the therapeutic efficacy is still not satisfactory (5). Therefore, more studies are required to fully elucidate the pathogenesis of colon cancer and to identify potential therapeutic targets for this disease.

Ras-related C3 botulinum toxin substrate 1 (RAC1) is an important member of the Rho family of GTPases [Rac, Rho and cell division cycle (CDC)42], which are molecular switches that regulate key cellular activities, including cell proliferation, apoptosis, gene expression and directional movement by cytoskeleton remodeling (6-9). Numerous studies have demonstrated that abnormal RAC1 signaling is associated with various human diseases, including cancer, inflammation, neurodegenerative disorders, kidney disorders and cardiovascular diseases (10). In addition, dysregulated RAC1 expression and activity has been detected in various types of cancer cell, including colon cancer (11), gastric cancer (12), lung cancer (13) and breast cancer cells (14), and it has been reported to modulate cancer cell proliferation, inva- 
sion, metastasis and epithelial mesenchymal transition (EMT) by regulating several cancer-associated signaling pathways, including p21-activated kinases (PAK1-3), actin-binding LIM kinases (LIMK1 and LIMK2), Wnt, phosphoinositol 3-kinase and nuclear factor (NF)- $\mathrm{B}(10,15-18)$. Therefore, it has been hypothesized that RAC1 represents an attractive therapeutic target, due to its role in promoting cancer initiation (10,15-18).

RAC1 overexpression can initiate intestinal stem cell proliferation and regeneration (19), thus resulting in accelerated tumorigenic processes, reduced survival times (20), and disruption of RAC1-mediated immune responses governing neutrophil chemotaxis and apoptosis-associated carcinogenesis in ulcerative colitis (21). Overexpression of the RAC1 splice variant RAC1b is also correlated with poor prognosis in patients with metastatic colorectal cancer (11). Furthermore, increased $\mathrm{RAC1}$ or RAC1b expression can promote cellular transformation, thereby enhancing colorectal cancer cell survival (22); conversely, silencing of RAC1 expression can induce apoptosis and cell cycle arrest, and inhibit proliferation of colon cancer cells. Although previous studies have demonstrated that abnormal RAC1 signaling is associated with the pathogenesis of colon cancer, it remains unclear as to whether RAC1 signaling mechanisms regulate colon cancer.

In our previous study, RAC1 mRNA expression was downregulated in HT-29 colon cancer cells following treatment with the anticancer agent diallyl disulfide (DADS) $(23,24)$. An additional study indicated that DADS may suppress SW480 cell migration and invasion by downregulating the RAC1-Rho-associated protein kinase 1 (ROCK1)/PAK1-LIMK1-actin-depolymerizing factor/cofilin signaling pathway (24).

Accordingly, the present study used RNA interference (RNAi) technology to silence $R A C 1$ gene expression in colon cancer cells. Subsequently, cell proliferation, apoptosis and cell cycle distribution were evaluated, in order to determine the role of RAC1 in colon cancer cells. Gene expression profiles were analyzed and bioinformatics analysis was performed to determine the possible molecular mechanisms through which short hairpin (sh)RNA-induced silencing of RACl modulated cell proliferation in colon cancer.

\section{Materials and methods}

Cell lines and culture. The human colon cancer cell lines used in the present study (i.e., HT-29, SW620 and HCT116 cells) and 293T cells were purchased from China Typical Culture Center (Wuhan, China). The cells were cultured in Dulbecco's modified Eagle's medium (DMEM) supplemented with $100 \mathrm{ml} / \mathrm{l}$ fetal bovine serum (FBS) (both from Gibco; Thermo Fisher Scientific, Inc., Waltham, MA, USA), $100 \mathrm{U} / \mathrm{ml}$ penicillin and $100 \mathrm{U} / \mathrm{ml}$ streptomycin at $37^{\circ} \mathrm{C}$ in a humidified atmosphere containing $5 \% \mathrm{CO}_{2}$.

Design and lentiviral packaging of RACl shRNA. Three pairs of shRNA sequences targeting the human $R A C l$ gene were designed using the latest version of the online RNAi design web tool (http://jura.wi.mit.edu/bioc/siRNA), as listed in Table I. The negative control duplexes of shRNA (shRNA-NC) were random sequences (TTCTCCGAACGTGTCACGT), which did not target any known mammalian gene, using the Blast website (https://blast.ncbi.nlm.nih.gov/Blast.cgi). The shRNA sequences were then cloned into the lentiviral vector GV248 (hU6-MCS-Ubi-EGFP-IRES-Puro; Shanghai GeneChem Co., Ltd., Shanghai, China). Lentivirus (LV) (LV-shRNA-RAC1 and LV-shRNA-NC) amplification and packaging was conducted according to the lentiviral packaging protocol (Shanghai GeneChem Co., Ltd.). Briefly, the 293T packaging cell line was cotransfected with GV248 carrying shRNA (LV-shRNA-RAC1 and LV-shRNA-NC) and pHelper plasmids. The next day, medium was replaced with fresh DMEM and culture was continued for $24 \mathrm{~h}$ at $37^{\circ} \mathrm{C}$. The viral supernatant was then collected, filtered, concentrated and stored in small aliquots at $-80^{\circ} \mathrm{C}$ for titration and cell infection.

Infection of colon cancer cells with LV-shRNA. Colon cancer cells were seeded in 6 -well plates $\left(6 \times 10^{5}\right.$ cells/well $)$ and were incubated for $24 \mathrm{~h}$ in a humidified atmosphere. The cells were divided into three groups: KD group, NC group and control group (untreated colon cancer cells). Cells in the KD and $\mathrm{NC}$ groups were infected with LV-shRNA-RAC1 or LV-shRNA-NC, respectively, at a multiplicity of infection of 10, according to the manufacturer's protocol (Shanghai GeneChem Co., Ltd.). After $24 \mathrm{~h}$ at $37^{\circ} \mathrm{C}$, the medium was replaced with fresh DMEM and cells were cultured for a further $48 \mathrm{~h}$. The lentivirus contained the green fluorescent protein (GFP), and the number of GFP positive cells were counted by inverted fluorescence microscopy (Olympus IX53; Olympus Co., Ltd., Shanghai, China). Finally, the cells were harvested and prepared for subsequent analysis.

$R N A$ extraction and reverse transcription-quantitative $P C R$ $(R T-q P C R)$. Total RNA was isolated from cells using TRIzol ${ }^{\circledR}$ reagent (Invitrogen; Thermo Fisher Scientific, Inc.). RT-qPCR was then performed. The RT-qPCR primers for $R A C l$ and GAPDH (internal control) were synthesized by Sangon Biotech Co., Ltd. (Shanghai, China). RT was performed using a FastQuant RT kit (Tiangen Biotech Co., Ltd., Beijing, China) according to the manufacturer's protocol. The PCR primers for $R A C 1$ and $G A P D H$ were as follows: $R A C 1$, forward 5'-ATGTCCGTGCA AAGTGGTATC-3', reverse 5'-CTCGGATCGCTTC GTCAAACA-3'; and GAPDH, forward 5'-GCCAAAAGGGTC ATCATCTC-3' and reverse 5'-GTAGAGGCAGGGATG ATGTTC-3'. qPCR was performed using Taq PCR MasterMix (Tiangen Biotech Co., Ltd.) and a ViiA ${ }^{\mathrm{TM}}$ system (Applied Biosystems; Thermo Fisher Scientific, Inc.). The thermal cycling conditions were as follows: Initial denaturation at $95^{\circ} \mathrm{C}$ for $60 \mathrm{sec}$, 40 cycles of amplification at $95^{\circ} \mathrm{C}$ for $20 \mathrm{sec}$, annealing and extension at $60^{\circ} \mathrm{C}$ for $30 \mathrm{sec}$. GAPDH was used as an internal control for PCR amplification. The data were analyzed using the $2^{-\Delta \Delta \mathrm{Ct}}$ method (25).

Proliferation assays. Cells were trypsinized $72 \mathrm{~h}$ postinfection and were seeded in 96-well plates in triplicate ( $2 \times 10^{3}$ cells/well). Following adherence, the cells were exposed to DMEM containing $0.5 \%$ FBS for $0,12,24,48$ or $72 \mathrm{~h}$ at $37^{\circ} \mathrm{C}$, and the effects of $R A C l$ knockdown on colon cancer cell proliferation were evaluated by MTT colorimetric assays. Briefly, the medium was removed and replaced with medium containing $5 \mathrm{mg} / \mathrm{ml} \mathrm{MTT}$. The cells were then incubated for $4 \mathrm{~h}$ at $37^{\circ} \mathrm{C}$, after which $100 \mu \mathrm{l}$ dimethyl sulfoxide solution was 
Table I. shRNA sequences targeting RAC1.

\begin{tabular}{llll}
\hline \multicolumn{1}{c}{ Target } & Sense & Antisense \\
\hline RAC1-shRNA-1 & 5'-TTCTTAACATCACTGTCTT-3' & 5'-ccTTCTTAACATCACTGTCTT-3' & 5'-AAGACAGTGATGTTAAGAAgg-3' \\
RAC1-shRNA-2 & 5'-CAAACAGATGTGTTCTTAA-3' & 5'-cgCAAACAGATGTGTTCTTAA-3' & 5'-TTAAGAACACATCTGTTTGcg-3' \\
RAC1-shRNA-3 & 5'-TGAAGAAGAGGAAGAGAAA-3' & 5'-cgTGAAGAAGAGGAAGAGAAA-3' 5'-TTTCTCTTCCTCTTCTTCAcg-3'
\end{tabular}

RAC1, Ras-related C3 botulinum toxin substrate 1; shRNA, short hairpin RNA.

Table II. List of primary antibodies used for western blotting.

\begin{tabular}{lllccc}
\hline Protein & Description & Vendor & $\begin{array}{c}\text { Product } \\
\text { code }\end{array}$ & Dilution & $\begin{array}{c}\text { Molecular } \\
\text { weight }\end{array}$ \\
\hline Cyclin D1 & Rabbit & Abcam & ab16663 & $1: 100$ & $33 \mathrm{kDa}$ \\
BAD & Rabbit & Abcam & ab32445 & $1: 2,000$ & $23 \mathrm{kDa}$ \\
RAC1 & Rabbit & Abcam & ab97568 & $1: 200$ & $21 \mathrm{kDa}$ \\
GAPDH & Rabbit & Abcam & ab9485 & $1: 2,000$ & $37 \mathrm{kDa}$ \\
\hline
\end{tabular}

BAD, B-cell lymphoma 2-associated agonist of cell death; RAC1, Ras-related C3 botulinum toxin substrate 1 .

added. A microplate reader was used to measure absorbance at $570 \mathrm{~nm}$ for each well. The growth inhibition rate was calculated as follows: Growth inhibition rate $=1-\mathrm{A}_{570 \mathrm{~nm}}$ of treated cells/A $/ 570 \mathrm{~nm}$.

Colony formation assay. Colon cancer cells from each group were plated in 6-well plates $(1,000$ cells/well) and were incubated for 15 days at $37^{\circ} \mathrm{C}$ in a humidified atmosphere; the medium was replaced every 3 days. On day 15 , the cells were washed with PBS, fixed with $4 \%$ paraformaldehyde for $30 \mathrm{~min}$ at $25^{\circ} \mathrm{C}$ and stained with Giemsa (Tiangen Biotech Co., Ltd.) for $15 \mathrm{~min}$. The number of colonies containing $>50$ cells was counted under an inverted microscope (Olympus Co., Ltd.).

Affymetrix microarray analysis. Gene chip assays and data analysis were performed by Shanghai GeneChem Co., Ltd. using the GeneChip PrimeView Human Gene Expression Array (cat. no. 901838; Affymetrix; Thermo Fisher Scientific, Inc.) according to the manufacturer's protocol. Briefly, three biological replicates collected from each group were subjected to microarray analysis. Total RNA was extracted from $R A C 1$-knockdown cells and NC cells, and RNA quality and quantity were measured using a NanoDrop spectrophotometer (ND-1000; NanoDrop Technologies; Thermo Fisher Scientific, Inc., Wilmington, DE, USA). RNA integrity was determined by gel electrophoresis, and purified total RNA was subsequently subjected to DNase I treatment. For microarray analysis, total RNA (300 ng) was first reverse transcribed into a double-stranded cDNA template. Biotin-labeled complementary RNA (cRNA) was then synthesized, amplified and purified by in vitro transcription of the double-stranded cDNA template using T7 RNA polymerase. The purified cRNA was fragmented and prepared for hybridization onto the GeneChip cartridge arrays. Hybridization, washing and staining were performed using a GeneChip Hybridization Wash and Stain kit (Affymetrix; Thermo Fisher Scientific, Inc.) according to the manufacturer's protocol. Scanning of hybridized arrays was performed using a GeneChip Scanner 3000 (Affymetrix; Thermo Fisher Scientific, Inc.). The data were analyzed with Microarray Suite version 5.0 (MAS 5.0) using Partek Genomics Suite software (Affymetrix; Thermo Fisher Scientific, Inc.). Expression values underwent Robust Multiarray Averaging normalization and fold-change values were then calculated using the least-squares mean between samples. The significance of differences in gene expression in the different groups (P-value) was estimated using Student's t-test. Genes with changes in expression $\geq 2$-fold $(\mathrm{P}<0.05)$ were regarded as differentially expressed.

Cell cycle and apoptosis analysis. Colon cancer cells were harvested and fixed in $70 \%$ ethanol at $4^{\circ} \mathrm{C}$ for $24 \mathrm{~h}$ after cells were grown to $80 \%$ confluence. Fixed cells were washed with PBS and suspended in $1 \mathrm{ml}$ propidium iodide (PI) staining reagent $(20 \mathrm{mg} / 1 \mathrm{RNase} \mathrm{A}$ and $50 \mathrm{mg} / \mathrm{l} \mathrm{PI})$. Samples were then incubated in the dark for $30 \mathrm{~min}$ at $25^{\circ} \mathrm{C}$ prior to cell cycle analysis. Cell cycle distribution was determined and analyzed using flow cytometry (FACSCalibur; Becton-Dickinson, San Jose, CA, USA).

The apoptotic rate was determined using an Annexin V-fluorescein isothiocyanate (FITC) detection kit (cat. no. 88-8007; eBioscience; Thermo Fisher Scientific, Inc.). Specific binding of Annexin V-FITC was performed by incubating the cells for $15 \mathrm{~min}$ at room temperature in binding buffer (10 mM HEPES, $140 \mathrm{mM} \mathrm{NaCl}, 2.5 \mathrm{mM} \mathrm{CaCl}_{2}$, pH 7.4) containing a saturating concentration of Annexin V-FITC. After incubation, $1 \times 10^{6}$ colon cancer cells of each group were harvested and fixed in $70 \%$ ethanol at $4^{\circ} \mathrm{C}$ for $24 \mathrm{~h}$ after cells were grown to $80 \%$ confluence. Cells were analyzed using FlowJo software (Tree Star, Inc., Ashland, OR, USA).

Western blot analysis. Western blot analyses were performed as previously described (8). Briefly, colon cancer cells were harvested, rinsed twice with cold PBS and incubated in lysis buffer (cat. no. P0013; Beyotime; Jiangsu, China). Following centrifugation at $12,000 \times \mathrm{g}$ for $30 \mathrm{~min}$ at $4^{\circ} \mathrm{C}$, the amount of protein in the supernatant was determined using bicinchoninic acid protein assay reagent. Equal amounts of protein $(30 \mu \mathrm{g})$ were completely vortexed with $2 \mathrm{X}$ SDS-gel buffer and boiled for $5 \mathrm{~min}$ at $100^{\circ} \mathrm{C}$ to dissolve bound proteins. Whole-cell lysates were then separated by $10 \%$ SDS-PAGE and were transferred to polyvinylidene difluoride membranes, which were blocked with $50 \mathrm{~g} / 1$ nonfat milk at $25^{\circ} \mathrm{C}$ for $1.5 \mathrm{~h}$. The association between RAC1 and differential expression genes involved in cancer-related pathways was investigated with 
A
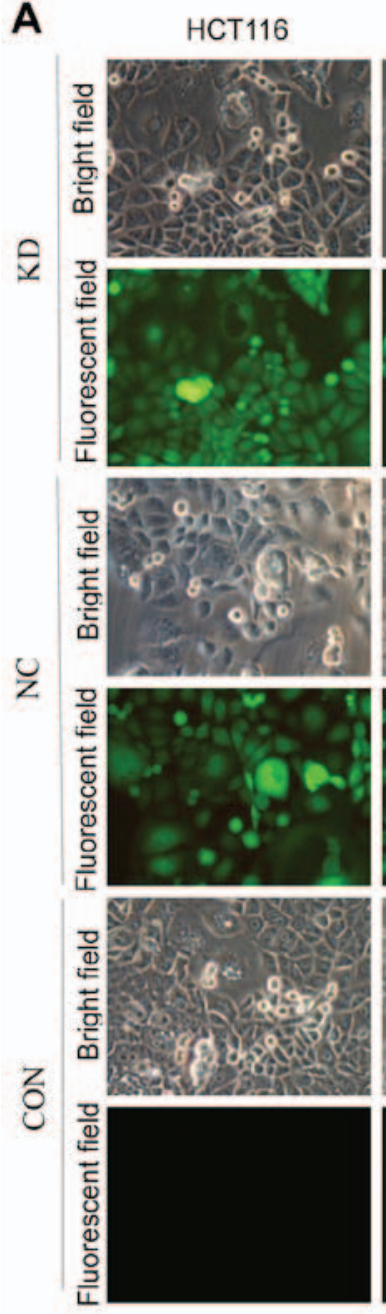

HT-29
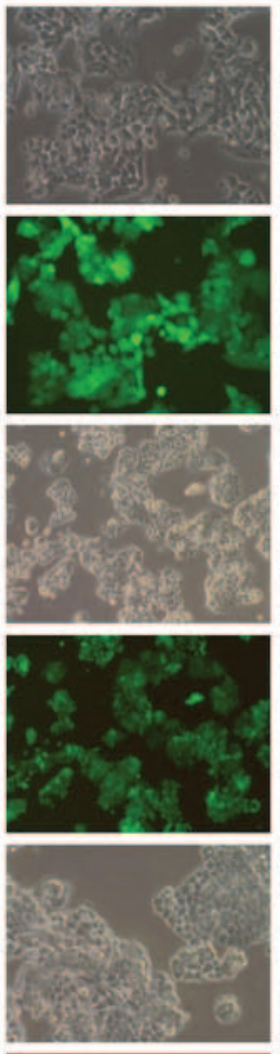
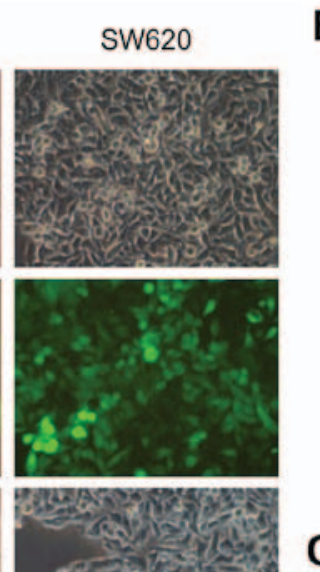
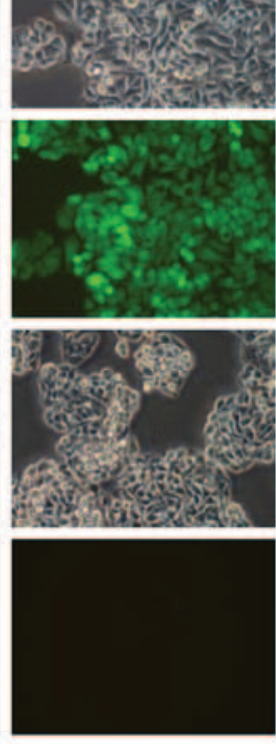

B

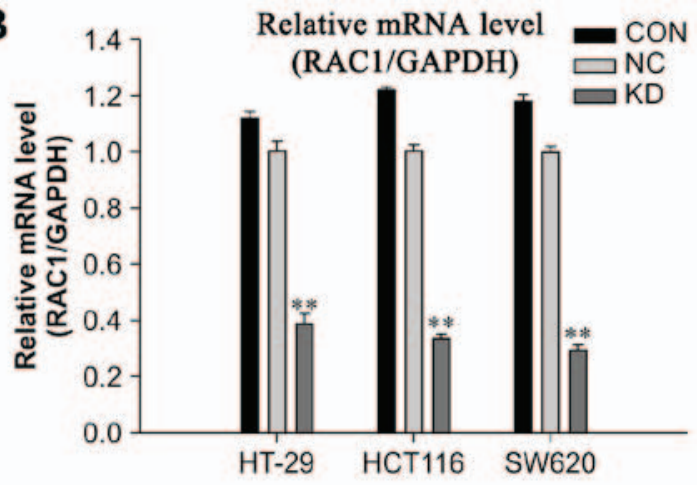

C

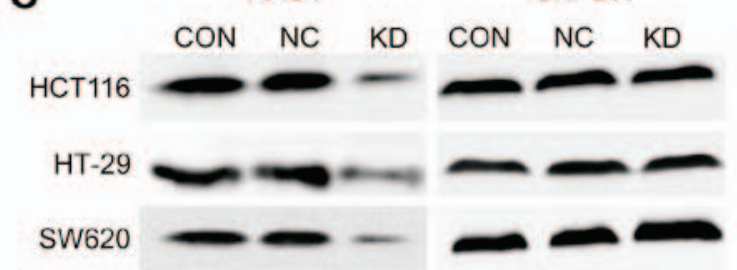

D

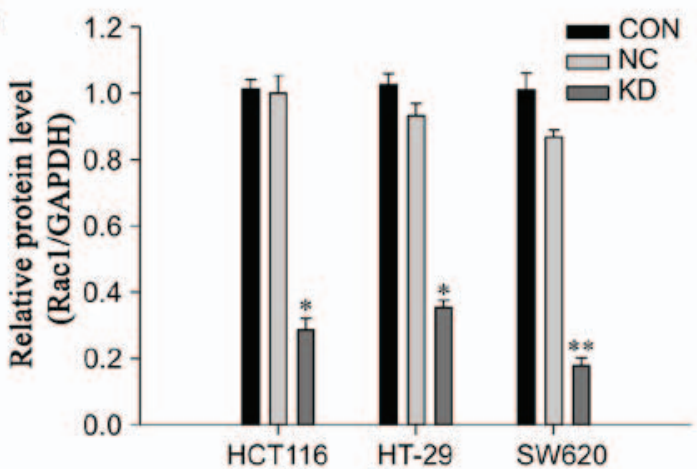

Figure 1. Effects of shRNA on RAC1 expression in colon cancer cells. (A) Representative images of colon cancer cells transfected with LV-shRNA-RAC1 or LV-NC for $48 \mathrm{~h}$ and of untreated cells (CON) (magnification, x200). Green fluorescent protein expression indicated that the cells had been successfully infected with the shRNA. Quantitative polymerase chain reaction analysis of RAC1 (B) mRNA and (D) protein expression. (C) Western blot analysis of RAC1 protein expression. GAPDH was used as an internal control. Data are presented as the means \pm standard deviation. ${ }^{*} \mathrm{P}<0.05$ and ${ }^{* *} \mathrm{P}<0.01$ vs. $\mathrm{NC}$. CON, control; KD, knockdown; LV, lentivirus; NC, negative control; RAC1, Ras-related C3 botulinum toxin substrate 1; shRNA, short hairpin RNA.

Ingenuity Pathway Analysis (IPA), a web delivered tool(www. ingenuity.com). Proteins were detected following incubation of membranes with specific primary antibodies (Table II) at $4^{\circ} \mathrm{C}$ overnight, and horseradish peroxidase (HRP)-conjugated secondary antibodies (ab6721; dilution 1:2,000; Abcam, Shanghai, China) for $1 \mathrm{~h}$ at $25^{\circ} \mathrm{C}$. The membranes were then incubated in SuperSignal enhanced chemiluminescence-HRP detection reagent (cat. no. P1108; Beyotime) for $1 \mathrm{~min}$, and semi-quantitative data were obtained using a computing densitometer with a scientific imaging system (Tanon 5500; Shanghai Tian Neng Technology Co., Ltd., Shanghai, China). GAPDH was used as a loading control for western blot analysis.

Statistical analysis. Data were analyzed using SPSS 18.0 software (SPSS, Inc., Chicago, IL, USA). Measurement data (mRNA/protein levels, cell cycle, cell apoptosis, colony formation and proliferation) are presented as the means \pm standard deviation from at least three independent experiments. Data were analyzed by Student's t-test or one-way analysis of variance followed by Fisher's post hoc test. $\mathrm{P}<0.05$ was considered to indicate a statistically significant difference.

\section{Results}

Effects of shRNA on RAC1 expression in colon cancer cells. The expression levels of RAC1 were detected in three colon cancer cell lines (HT-29, HCT116 and SW620). There were no significant differences in the expression of RAC1, and all three cell lines exhibited high levels of RAC1 mRNA and protein (Fig. 1). Conversely, the expression levels of RAC1 were stably reduced using LV-mediated RNAi, and infection efficiency of LV-shRNA-RAC1 and LV-NC was determined using fluorescence microscopy. The results revealed that the majority of cells $(>95 \%)$ were successfully infected with shRNA (Fig. 1A). The interference efficiency was observed by RT-qPCR and western blotting $72 \mathrm{~h}$ postinfection. The expression levels of RAC1 mRNA and protein were significantly decreased in cells in the $\mathrm{KD}$ group compared with in the $\mathrm{NC}$ and control groups $(\mathrm{P}<0.01)$. In the KD group of HCT116, HT-29 and SW620 cells, RAC1 protein levels were reduced by $71.4,64.6$ and $82.2 \%$, respectively, when compared with the NC group (Fig. 1B-D). These results indicated that $\mathrm{LV}$-mediated $R A C 1$ shRNA was able to efficiently downregulate RAC1 expression in colon cancer cells. 

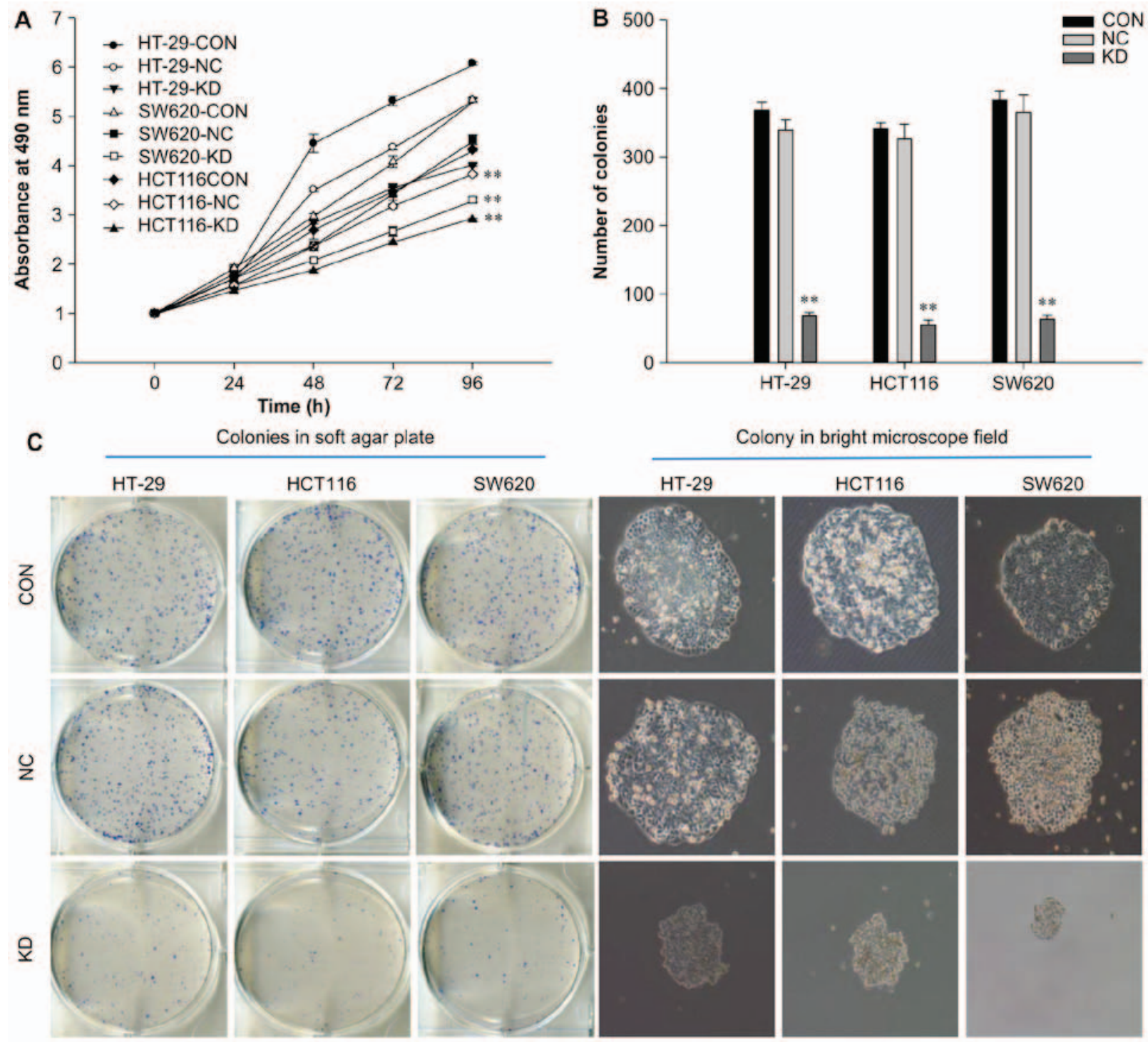

Figure 2. Effects of RACl silencing on colon cancer cell proliferation. (A) MTT assays were used to measure cell proliferation in LV-infected and untreated colon cancer cells. (B) Average number of colonies in colon cancer cells infected with LV-shRNA-RAC1 or LV-NC and in untreated cells. (C) Representative images of colony formation assays for colon cancer cells in 6-well soft agar plates. The size of each colony was observed using a bright-field microscope (magnification, $\mathrm{x} 200$ ). Data are presented as the means \pm standard deviation. ${ }^{* *} \mathrm{P}<0.01$ vs. NC. CON, control; KD, knockdown; LV, lentivirus; NC, negative control; RAC1, Ras-related C3 botulinum toxin substrate 1; shRNA, short hairpin RNA.

RACl knockdown suppresses the proliferation and colony formation of colon cancer cells. MTT assays were used to determine whether silencing $R A C l$ expression inhibited colon cancer cell viability. Time-dependent inhibition of cell growth was determined in the KD group, whereas no significant inhibitory effects were observed in the $\mathrm{NC}$ and control groups (Fig. 2A). Cell proliferation was significantly inhibited after 4 days of infection $(\mathrm{P}<0.01)$, with proliferation decreased by $24.6,11.4$ and $27.2 \%$ in the KD group of HT-29, HCT116 and SW620 cells, respectively, when compared with the NC group. In addition, following $R A C l$ knockdown, the colony-forming capacity of colon cancer cells was significantly decreased by $60-80 \%(\mathrm{P}<0.01)$, and colony size was reduced compared with in the $\mathrm{NC}$ and control groups $(\mathrm{P}<0.01$; Fig. $2 \mathrm{~B}$ and $\mathrm{C})$. These data suggested that RAC1 may serve a critical role in colon cancer cell proliferation, particularly in SW620 KD group. Therefore, SW620 cells were selected for subsequent gene chip analysis.
RACl knockdown induces differential gene expression. To explore the molecular effectors associated with RAC1 activity in colon cancer, microarray analysis was performed to determine the mRNA profiles of SW620 cells following $R A C l$ knockdown (Fig. 3). From this analysis, 1,215 transcripts were identified as having $\geq 1.5$-fold differential expression; 604 genes were upregulated, whereas 611 genes were downregulated after $R A C 1$ silencing (Fig. 3B). The results of unsupervised hierarchical clustering of gene expression levels demonstrated that SW620 cells with $R A C l$ knockdown were easily distinguishable from SW620 cells without $R A C 1$ knockdown, and six samples were essentially partitioned into two groups: The first containing knockdown cells and the other containing cells without $R A C l$ knockdown (Fig. 3A). All differentially expressed genes were divided into groups according to their biological functions using Gene Ontology (GO) terms and Kyoto Encyclopedia of Genes and Genomes (KEGG) analysis (https://david.ncifcrf.gov/). The main functional groups and molecular pathways included 

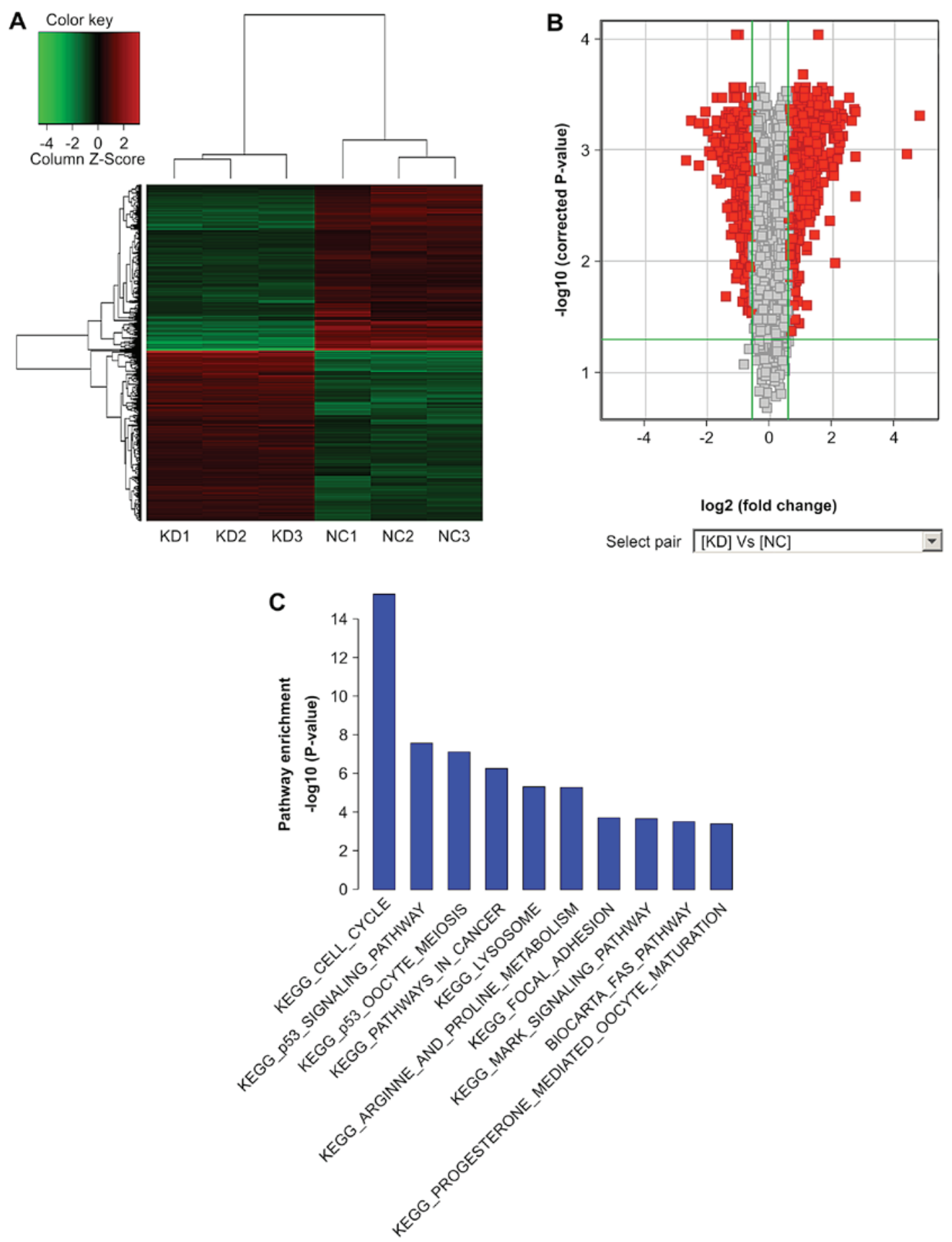

Figure 3. (A) Unsupervised hierarchical clustering based on the mRNA expression levels of genes. Gene microarray expression profiles from three sets of matched SW620 cells transfected with LV-short hairpin RNA-Ras-related C3 botulinum toxin substrate 1 (KD1-KD3) and LV-NC (NC1-NC3). Red indicates upregulated genes, green indicates downregulated genes. (B) Volcano plot analysis based on mRNA expression levels. The vertical green lines correspond to 1.5 -fold increases or decreases in expression, and the horizontal green line represents a P-value of 0.05 . Therefore, red points in the plot represent differentially expressed genes with statistical significance. (C) Top 10 signal pathways are listed according to their P-values, as determined by KEGG analysis. KD, knockdown; KEGG, Kyoto Encyclopedia of Genes and Genomes; LV, lentivirus; NC, negative control.

cell cycle and apoptosis, cell adhesion, metabolic process, mitosis and cancer-related pathways. Of these, the relationship between cell cycle and $R A C l$ silencing was the most significant according to $\mathrm{GO}$ analysis $(\mathrm{P}=\mathrm{P}=5.19 \mathrm{E} 16,-\log 10(5.19 \mathrm{E}$ $16)=15.28) ;>140$ genes, including cyclin D1 (CCND1), cyclin-dependent kinase $1(C D K 1)$, cyclin $\mathrm{B} 1(C C N B 1)$, B-cell lymphoma (Bcl)-2-associated agonist of cell death $(B A D)$, caspase-8 (CASP8) and MYC proto-oncogene, bHLH tran- scription factor $(M Y C)$, were involved in this process, and the most significant differences in expression were found in cell adhesion-related genes, some of which are listed in Table III. Through KEGG analysis, it was demonstrated that silencing $R A C l$ expression inhibited the proliferation of colon cancer cells, potentially via 553 signaling, mitogen-activated protein kinase (MAPK) signaling or cancer-related pathways. The top 10 pathways are listed in Fig. 3C according to their P-values. 


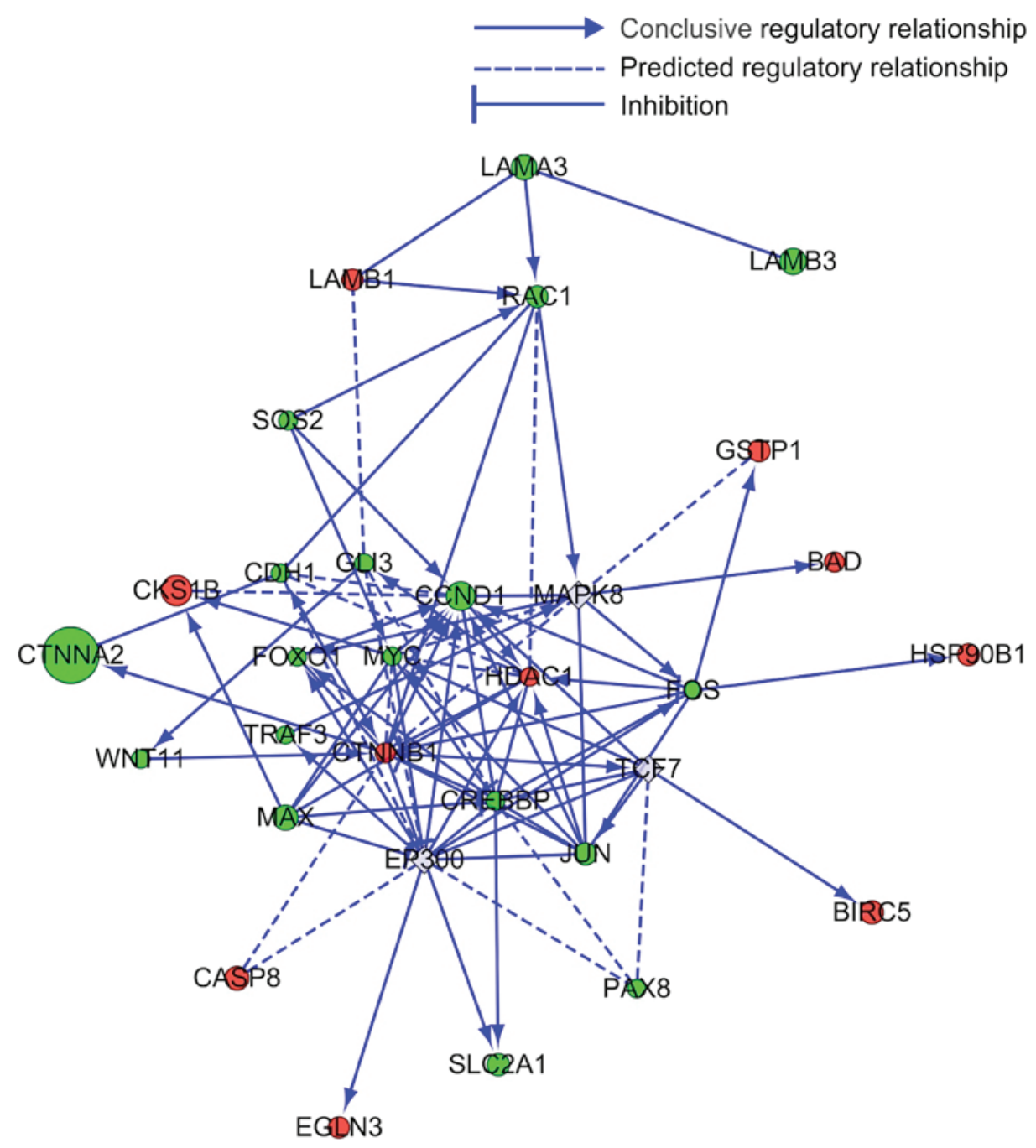

Figure 4. Bioinformatics prediction of genes interacting with RACl using Ingenuity Pathway Analysis. Green represents downregulated genes, red represents upregulated genes, grey represents genes that were automatically added by the system. Dot size represents degree of differential expression between the knockdown and negative control groups. RACl, Ras-related C3 botulinum toxin substrate 1 .

From these data, the present study further investigated the association between $R A C 1$ and 29 genes involved in cancer-related pathways through bioinformatics analysis and prediction. The results indicated that $R A C 1$ regulated the expression of these genes by direct or indirect interactions (Fig. 4).

RACl knockdown induces cell cycle arrest and apoptosis. To further validate the effects of RACl knockdown on the viability of SW620 colon cancer cells, flow cytometry was used to detect alterations in cell cycle progression and apoptosis following RACl knockdown (Figs. 5 and 6). The results demonstrated that the apoptotic rate of the KD group (10.45\%) was significantly higher compared with in the NC and control groups (5.45 and 4.42\%, respectively; $\mathrm{P}<0.01$ ) (Fig. 6A and $\mathrm{B}$ ). Compared with the NC group, the proportion of cells in $\mathrm{S}$ phase in the KD group was significantly decreased from 45.65 to $32.68 \%(\mathrm{P}<0.01)$, whereas the ratio of cells in the $\mathrm{G}_{0} / \mathrm{G}_{1}$ phase was significantly increased from 43.91 to $54.14 \%$ $(\mathrm{P}<0.01)$ (Fig. 5A and B). However, there were no significant differences between the $\mathrm{NC}$ and control groups, thus indicating that $R A C l$ knockdown interfered with cell cycle progression, leading to cell cycle arrest in $\mathrm{G}_{1}$ phase in the $\mathrm{KD}$ group.
To further investigate the molecular mechanisms through which $R A C 1$ knockdown inhibited the proliferation of colon cancer cells, potentially via $\mathrm{G}_{0} / \mathrm{G}_{1}$ cell cycle arrest and increased apoptosis, cyclin D1 and BAD protein expression levels were evaluated by western blotting after RAC1 knockdown in SW620 cells. Notably, BAD expression was upregulated, whereas cyclin D1 expression was downregulated in the KD group compared with in the $\mathrm{NC}$ and control groups (Figs. 5C and D, and $6 \mathrm{C}$ and $\mathrm{D}$ ). These data suggested that RAC1 knockdown may suppress the proliferation of colon cancer cells by inducing apoptosis and cell cycle arrest, potentially through upregulation of BAD and downregulation of cyclin D1.

\section{Discussion}

Colorectal cancer is the third most common malignant tumor worldwide and the second leading cause of cancer-associated mortality in developed countries $(1,26)$. Despite marked improvements in the diagnosis and treatment of colon cancer, the incidence and mortality rates of this disease are still increasing $(1,26)$. Personalized medicine may lead to improvements in the survival rates of patients with colon cancer; 

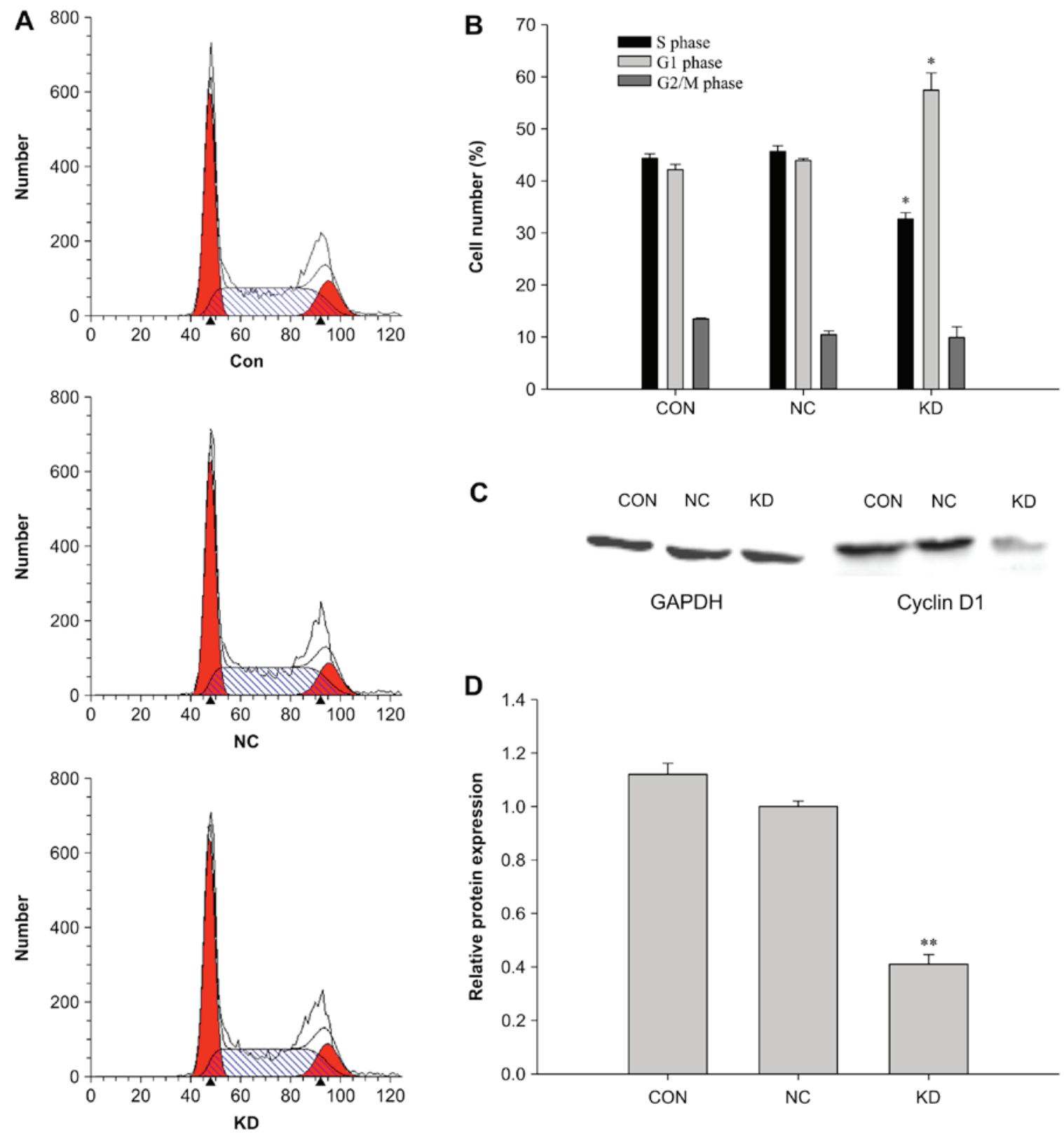

Figure 5. Effects of RAC1 silencing on cell cycle progression of SW620 cells. (A) Representative results of cell cycle analysis, as determined by flow cytometry. (B) Cell cycle distribution of SW620 cells in each group. (C) Representative results of western blot analysis of cyclin D1 protein expression. (D) Relative protein expression levels of cyclin D1. Data are presented as the means \pm standard deviation. ${ }^{*} \mathrm{P}<0.05$ and ${ }^{* * *} \mathrm{P}<0.01$ vs. NC. CON, control; KD, knockdown; NC, negative control; RACl, Ras-related C3 botulinum toxin substrate 1 .

however, additional studies are required for the identification of additional potential therapeutic targets, and the development of targeted agents with high efficacy and low toxicity $(27,28)$. Numerous studies have reported that abnormal RAC1 signaling is associated with various human diseases, and that RAC1 expression and activity are dysregulated in numerous types of cancer, including colon cancer $(10,15)$. Overexpression of RAC1 triggers tumor initiation and is associated with the metastasis and invasion of cancer cells; therefore, RAC1 may be a potent therapeutic target for patients with malignant tumors $(10,15)$.

Downregulation of RAC1 can inhibit the proliferation of various cancer cells, including gastric cancer (12), colon cancer $(20)$ and breast cancer cells $(29)$, among others $(10,13,30)$. In the present study, the expression of RACl was silenced by LV-mediated RNAi. Subsequently, the proliferation and colony-forming abilities of HT-29, HCT116 and SW620 colon cancer cells were significantly inhibited, which is consistent with previous data. These findings indicated that RAC1 may serve an important role in maintaining the growth of colon cancer cells.

To improve understanding of the molecular mechanisms through which shRNA-induced silencing of $R A C l$ inhibits proliferation of colon cancer cells, a gene expression microarray analysis was conducted. The results demonstrated that $>1,200$ genes involved in RAC1 silencing were differentially expressed, including 604 upregulated and 611 downregulated genes. These genes were divided into various groups according to their biological function using GO terms and KEGG analysis. The main functional groups and signaling pathways included cell cycle, apoptosis, cell adhesion, metabolic process, mitosis, p53 signaling pathway and cancer-related pathways. 

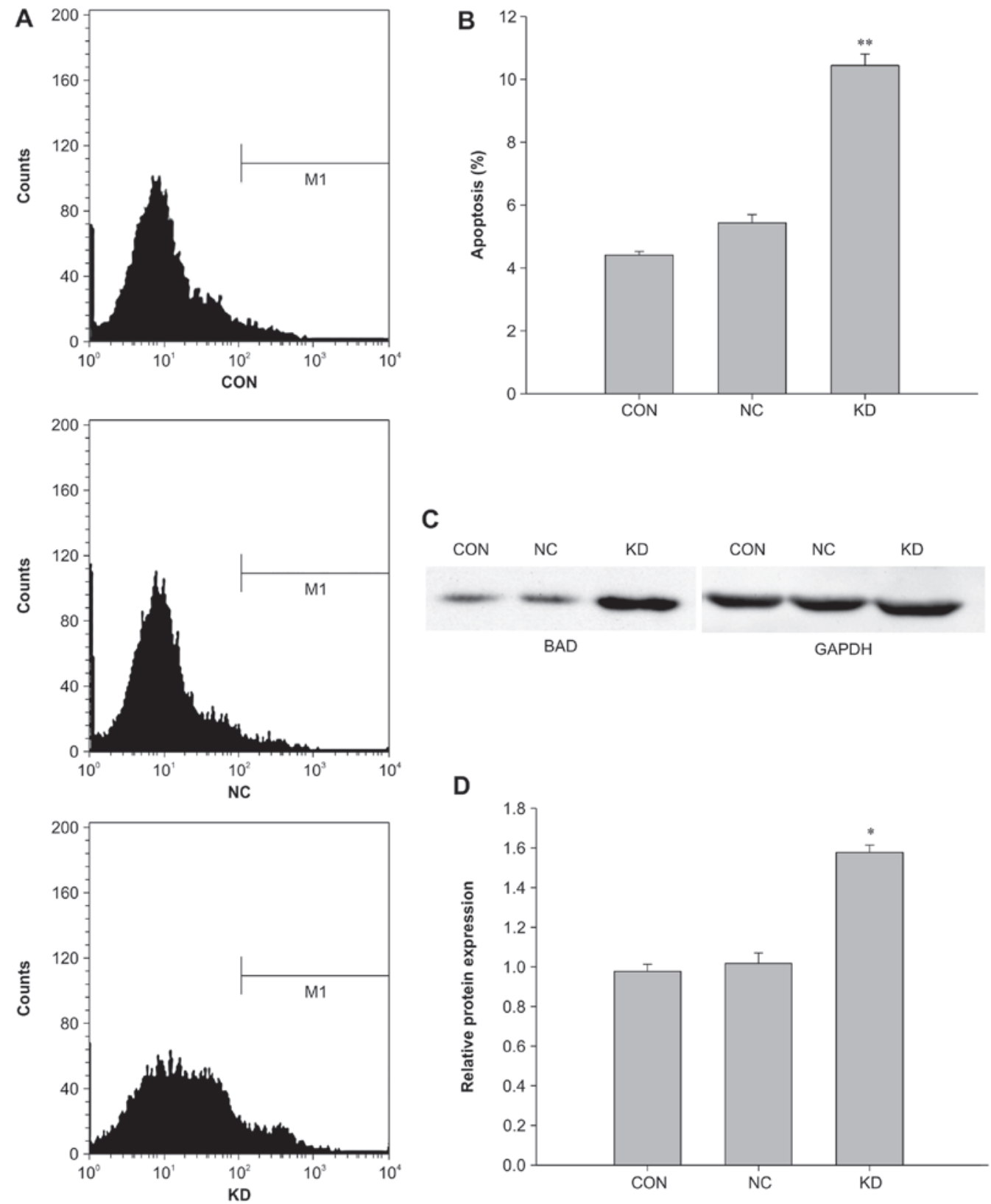

Figure 6. Effects of RAC1 silencing on apoptosis of SW620 cells. (A) Representative results of apoptosis analysis, as determined by flow cytometry. (B) Apoptotic rate of SW620 cells in each group. (C) Representative results of western blot analysis of BAD protein expression. (D) Relative protein expression levels of BAD. Data are presented as the means \pm standard deviation. " $\mathrm{P}<0.05$ and ${ }^{* *} \mathrm{P}<0.01$ vs. NC. BAD, B-cell lymphoma 2 -associated agonist of cell death; CON, control; KD, knockdown; NC, negative control; RACl, Ras-related C3 botulinum toxin substrate 1.

Notably, RAC1 has been reported to serve an important role in the regulation of various signaling pathways involved in apoptosis and cell cycle progression, and RAC1 has been revealed to facilitate tumor cell proliferation $(31,32)$. Consistent with these findings, the present results demonstrated that $R A C l$ knockdown in SW620 cells induced differential expression of $>140$ genes associated with the cell cycle and apoptosis, including $C C N B 1$, $C C N D 1$, Fos proto-oncogene, AP-1 transcription factor subunit $(F O S)$ and $M Y C$, which were downregulated, and $C A S P 8, B A D$ and $\beta$-catenin, which were upregulated, and genes involved in p53 signaling, MAPK signaling and cancer-related pathways.

Cancer may become autonomous if the genes that drive the cell cycle and apoptosis become dysregulated $(33,34)$. Cyclin/CDK complexes phosphorylate crucial target proteins that drive the cell through the cell cycle $(33,35)$. Cyclin D1, which is encoded by the CCND1 gene, forms a complex with CDK4 or CDK6, whose activity is required for the $\mathrm{G}_{1} / \mathrm{S}$ transition of the cell cycle $(33,35)$. The CCNB1 gene encodes the cyclin $\mathrm{B} 1$ protein, which has regulatory functions in mitosis. In addition, this protein forms a complex with p34 (CDC2), leading to generation of the maturation-promoting factor, which is expressed predominantly during $\mathrm{G}_{2} / \mathrm{M}$ phase $(33,35)$. Increased MYC protein expression can activate cyclin/CDK complexes, drive cells into the cell cycle and promote cell proliferation in numerous human cancers $(36,37)$. The tumor suppressor p53 can arrest growth by halting the cell cycle at $\mathrm{G}_{1} / \mathrm{S}$ checkpoint and initiate apoptosis by regulating the expression of cyclin D1, cyclin B1 and MYC (38). Cyclin D1 and cyclin B1 overexpression, potentially through inactivity of the p53 gene or activity of the MYC gene, has been reported 
Table III. Differentially expressed genes associated with the cell cycle, apoptosis and cell adhesion following Ras-related C3 botulinum toxin substrate 1 knockdown.

\begin{tabular}{|c|c|c|c|}
\hline Gene name & GenBank no. & Fold-change & Function \\
\hline$C C N D 1$ & NM_053056 & -2.4881644 & Cell cycle \\
\hline$C C N B 2$ & NM_004701 & 3.625082 & Cell cycle \\
\hline CHEK2 & NM_145862 & 1.6333724 & Cell cycle \\
\hline$C D C 25 C$ & NM_022809 & 4.5017295 & Cell cycle \\
\hline BUB1 & NM_004336 & 2.8708594 & Cell cycle \\
\hline SMC1A & NM_006306 & -1.6359816 & Cell cycle \\
\hline PTTG1 & NM_004219 & 2.4099076 & Cell cycle \\
\hline ESPL1 & NM_012291 & 2.1459587 & Cell cycle \\
\hline MCM2 & NM_004526 & -1.723211 & Cell cycle \\
\hline МСM6 & NM_005915 & -1.8482218 & Cell cycle \\
\hline ORC3 & NM_181837 & 1.6491874 & Cell cycle \\
\hline STAG2 & NM_006603 & 1.7200525 & Cell cycle \\
\hline$B U B 1 B$ & NM_001211 & 1.8905722 & Cell cycle \\
\hline TTK & NM_003318 & 2.1164258 & Cell cycle \\
\hline BUB3 & NM_004725 & 1.5317589 & Cell cycle \\
\hline$M Y C$ & NM_002467 & -1.549336 & $\begin{array}{l}\text { Cell cycle, } \\
\text { Cell apoptosis }\end{array}$ \\
\hline CASP8 & NM_033356 & 2.0469344 & Cell apoptosis \\
\hline$A R H G D I B$ & NM_001175 & -1.9277692 & Cell apoptosis \\
\hline CASP7 & NM_033338 & 1.9895566 & Cell apoptosis \\
\hline CASP2 & NM_032982 & -1.7764742 & Cell apoptosis \\
\hline CASP4 & NM_001225 & 1.9777244 & Cell apoptosis \\
\hline$B A D$ & NM_004322 & 1.6885499 & $\begin{array}{l}\text { Cell apoptosis, } \\
\text { Focal adhesion }\end{array}$ \\
\hline$J U N$ & NM_002228 & -1.892828 & Focal adhesion \\
\hline LAMA3 & NM_198129 & -2.1677043 & Focal adhesion \\
\hline$L A M B 1$ & NM_002291 & 1.8277249 & Focal adhesion \\
\hline$L A M B 3$ & NM_000228 & -2.2665424 & Focal adhesion \\
\hline$P A K 2$ & NM_002577 & -1.6881523 & Focal adhesion \\
\hline$I T G B 7$ & NM_000889 & -2.1417882 & Focal adhesion \\
\hline$I T G B 8$ & NM_002214 & -6.589815 & Focal adhesion \\
\hline COL6A1 & NM_001848 & -1.8742688 & Focal adhesion \\
\hline MYL5 & NM_002477 & -2.0736258 & Focal adhesion \\
\hline
\end{tabular}

to be correlated with tumor progression (39), shorter survival in patients with cancer and increased metastasis (36-39). Previous studies have reported that decreased expression of cyclin D1 $(40,41)$, MYC $(42,43)$ and cyclin B1 (43) using anticancer agents or RNAi may lead to $G_{1}$ or $G_{2} / M$ cell cycle arrest. Activation of the GTPase RAC1 can promote tumor cell proliferation through the abnormal expression of c-Jun, MYC and RAS, and silencing of RAC1 expression leads to cell cycle arrest, potentially through pathways involving PAK1 (44), cyclin D1 (29) and NF- $\mathrm{B}$ (45) in breast cancer, lung cancer and colon cancer (15). The present findings confirmed these previous results, demonstrating that $R A C 1$ knockdown induced SW620 cell cycle arrest at $G_{1}$ phase, and this process may be associated with the differential expression of numerous genes, including CCND1, CCNB1, CDC12 and MYC. Notably, the downregulation of cyclin D1 was further validated by western blotting, thus suggesting that silencing of $R A C l$ expression may induce $G_{1}$ arrest through this pathway.
A large family of genes that regulate apoptosis has been identified, and caspase- 8 and BAD are important members of this family (34). Caspase- 8 can activate downstream caspases that cause cell death, and BAD proteins are able to promote apoptosis by neutralizing the activity of anti-apoptotic proteins, such as Bcl-2 and Bcl-extra large. MYC protein can either activate CDK and cyclin genes, or suppress the transcription of apoptosis-associated genes $(36,46)$. Suppression of RAC1 expression has been reported to decrease the phosphorylation of MYC and inhibit cell proliferation (47). Furthermore, increased p38 MAPK expression leads to upregulation of FOS activity through a RAC1-dependent and CDC42-independent pathway, and co-expression of the dominant-negative mutants of FOS, p38 and RAC1 blocks MYC-mediated apoptosis (48). The present data demonstrated that knockdown of the $R A C l$ gene may induce apoptosis of SW620 colon cancer cells; numerous genes that are potentially involved in this process were identified by gene chip analysis, of which BAD upregulation was further confirmed by western blotting. These results may indicate that silencing $R A C l$ expression can induce cell apoptosis through a pathway involving BAD.

Previous studies have reported that RAC1 is involved in cancer invasion and metastasis through controlling cell motility and cell adhesion $(10,15)$. For example, RAC1 hyperactivation or overexpression drives the mesenchymal mode of cell migration by stimulating the formation of actin-rich membrane extensions $(49,50)$; promotes tumor-associated angiogenesis by regulating the balance of inhibitors and stimulators of endothelial cell proliferation, endothelial cell migration and capillary formation molecules $(15,51,52)$; controls the expression and release of matrix metalloproteinases required for proteolytic degradation of the extracellular matrix (ECM) $(10,53,54)$; and induces EMT by mediating cellular plasticity and ECM modulation $(10,30,55)$. In the present study, after silencing $R A C 1$ expression, some differentially expressed genes involved in cancer-related pathways were detected, including laminin subunit $\alpha 3$, Jun proto-oncogene, AP-1 transcription factor subunit, $M Y C$, laminin subunit $\beta 1, P A K 2$ and $R O C K 2$, which were downregulated, and thrombospondin 1 and $B A D$, which were upregulated; these genes are involved in cell motility and adhesion. Therefore, the present findings further supported that RAC1 promoted tumor invasion and metastasis through regulating cell motility and adhesion.

In conclusion, silencing $R A C 1$ expression inhibited colon cancer cell growth, promoted cell cycle arrest and enhanced apoptosis; these functions may be associated with the differential expression of numerous genes involved in various biological functions, including downregulation of CCNDI and upregulation of $B A D$. Further studies regarding these differentially expressed genes may allow a better understanding of the effects of RAC1 signaling dysregulation on the promotion of colon carcinogenesis.

\section{Acknowledgements}

The present study was supported by the National Natural Science Foundation of China (grant no. 81260321). The obtained microarray data were deposited in the Gene Expression Omnibus database (accession no. GSE78093). 


\section{References}

1. Chen W, Zheng R, Baade PD, Zhang S, Zeng H, Bray F, Jemal A Yu XQ and He J: Cancer statistics in China, 2015. CA Cancer J Clin 66: 115-132, 2016

2. Sideris M and Papagrigoriadis S: Molecular biomarkers and classification models in the evaluation of the prognosis of colorectal cancer. Anticancer Res 34: 2061-2068, 2014.

3. Holubec L, Polivka J Jr, Safanda M, Karas M and Liska V: The role of cetuximab in the induction of anticancer immune response in colorectal cancer treatment. Anticancer Res 36: 4421-4426, 2016.

4. Chen BJ, Wu YL, Tanaka Y and Zhang W: Small molecules targeting c-Myc oncogene: Promising anti-cancer therapeutics. Int J Biol Sci 10: 1084-1096, 2014.

5. Raskov H, Pommergaard HC, Burcharth $\mathbf{J}$ and Rosenberg $\mathbf{J}$ Colorectal carcinogenesis--update and perspectives. World J Gastroenterol 20: 18151-18164, 2014

6. Tejada-Simon MV: Modulation of actin dynamics by Rac1 to target cognitive function. J Neurochem 133: 767-779, 2015.

7. Fritz G and Henninger C: Rho GTPases: Novel players in the regulation of the DNA damage response? Biomolecules 5: 2417-2434, 2015.

8. Lawson CD and Burridge K: The on-off relationship of Rho and Rac during integrin-mediated adhesion and cell migration. Small GTPases 5: e27958, 2014

9. Pick E: Role of the Rho GTPase Rac in the activation of the phagocyte NADPH oxidase: Outsourcing a key task. Small GTPases 5: e27952, 2014.

10. Marei $\mathrm{H}$ and Malliri A: Racl in human diseases: The therapeutic potential of targeting Racl signaling regulatory mechanisms. Small GTPases: Jul 21, 2016 (Epub ahead of print).

11. Alonso-Espinaco V, Cuatrecasas M, Alonso V, Escudero P, Marmol M, Horndler C, Ortego J, Gallego R, Codony-Servat J, Garcia-Albeniz X, et al: RAClb overexpression correlates with poor prognosis in KRAS/BRAF WT metastatic colorectal cancer patients treated with first-line FOLFOX/XELOX chemotherapy. Eur J Cancer 50: 1973-1981, 2014.

12. Ji J, Feng X, Shi M, Cai Q, Yu Y, Zhu Z and Zhang J: Rac1 is correlated with aggressiveness and a potential therapeutic target for gastric cancer. Int J Oncol 46: 1343-1353, 2015.

13. Chen QY, Xu LQ, Jiao DM, Yao QH, Wang YY, Hu HZ, Wu YQ, Song J, Yan J and Wu LJ: Silencing of Racl modifies lung cancer cell migration, invasion and actin cytoskeleton rearrangements and enhances chemosensitivity to antitumor drugs. Int J Mol Med 28 : 769-776, 2011.

14. Hein AL, Post CM, Sheinin YM, Lakshmanan I, Natarajan A, Enke CA, Batra SK, Ouellette MM and Yan Y: RACl GTPase promotes the survival of breast cancer cells in response to hyper-fractionated radiation treatment. Oncogene 35: 6319-6329, 2016.

15. Bid HK, Roberts RD, Manchanda PK and Houghton PJ: RAC1: An emerging therapeutic option for targeting cancer angiogenesis and metastasis. Mol Cancer Ther 12: 1925-1934, 2013.

16. Lv Z, Hu M, Zhen J, Lin J, Wang Q and Wang R: Rac1/PAK1 signaling promotes epithelial-mesenchymal transition of podocytes in vitro via triggering $\beta$-catenin transcriptional activity under high glucose conditions. Int J Biochem Cell Biol 45: 255-264, 2013.

17. Kallergi G, Agelaki S, Markomanolaki H, Georgoulias V and Stournaras C: Activation of FAK/PI3K/Rac1 signaling controls actin reorganization and inhibits cell motility in human cancer cells. Cell Physiol Biochem 20: 977-986, 2007.

18. Myant KB, Cammareri P, McGhee EJ, Ridgway RA, Huels DJ, Cordero JB, Schwitalla S, Kalna G, Ogg EL, Athineos D, et al: ROS production and NF- $\kappa \mathrm{B}$ activation triggered by $\mathrm{RAC1}$ facilitate WNT-driven intestinal stem cell proliferation and colorectal cancer initiation. Cell Stem Cell 12: 761-773, 2013

19. Myant KB, Scopelliti A, Haque S, Vidal M, Sansom OJ and Cordero JB: Rac1 drives intestinal stem cell proliferation and regeneration. Cell Cycle 12: 2973-2977, 2013.

20. Espina C, Céspedes MV, García-Cabezas MA, Gómez del Pulgar MT, Boluda A, Oroz LG, Benitah SA, Cejas P, Nistal M, Mangues R, et al: A critical role for Racl in tumor progression of human colorectal adenocarcinoma cells. Am J Pathol 172: 156-166, 2008.

21. Yu C, Zhang S, Song L, Wang Y, Hwaiz R, Luo L and Thorlacius H: Racl signaling regulates neutrophil-dependent tissue damage in experimental colitis. Eur J Pharmacol 741: 90-96, 2014
22. Li G, Ying L, Wang H, Wei SS, Chen J, Chen YH, Xu WP, Jie QQ, Zhou Q, Li YG, et al: Raclb enhances cell survival through activation of the JNK2/c-JUN/Cyclin-D1 and AKT2/MCL1 pathways. Oncotarget 7: 17970-17985, 2016.

23. Huang YS, Xie N, Su Q, Su J, Huang C and Liao QJ: Diallyl disulfide inhibits the proliferation of HT-29 human colon cancer cells by inducing differentially expressed genes. Mol Med Rep 4: 553-559, 2011.

24. Zhou Y, Su J, Shi L, Liao Q and Su Q: DADS downregulates the Rac1-ROCK1/PAK1-LIMK1-ADF/cofilin signaling pathway, inhibiting cell migration and invasion. Oncol Rep 29: 605-612, 2013.

25. Livak KJ and Schmittgen TD: Analysis of relative gene expres $\neg$ sion data using real time quantitative PCR and the 2(Delta DeltaC(T)) method. Methods 25: 402 408, 2001.

26. Siegel RL, Miller KD and Jemal A: Cancer statistics, 2015. CA Cancer J Clin 65: 5-29, 2015.

27. Pohl M and Schmiegel W: Therapeutic strategies in diseases of the digestive tract - 2015 and beyond targeted therapies in colon cancer today and tomorrow. Dig Dis 34: 574-579, 2016.

28. Wang Y, Zhang J, Li L, Xu X, Zhang Y, Teng Z and Wu F: Identification of molecular targets for predicting colon adenocarcinoma. Med Sci Monit 22: 460-468, 2016.

29. Yoshida T, Zhang Y, Rivera Rosado LA, Chen J, Khan T, Moon SY and Zhang B: Blockade of Rac1 activity induces G1 cell cycle arrest or apoptosis in breast cancer cells through downregulation of cyclin D1, survivin, and X-linked inhibitor of apoptosis protein Mol Cancer Ther 9: 1657-1668, 2010.

30. Leng R, Liao G, Wang H, Kuang J and Tang L: Rac1 expression in epithelial ovarian cancer: Effect on cell EMT and clinical outcome. Med Oncol 32: 329, 2015.

31. Leve F and Morgado-Díaz JA: Rho GTPase signaling in the development of colorectal cancer. J Cell Biochem 113: 2549-2559, 2012.

32. Rathinam R, Berrier A and Alahari SK: Role of Rho GTPases and their regulators in cancer progression. Front Biosci (Landmark Ed) 16: 2561-2571, 2011.

33. Champeris Tsaniras S, Kanellakis N, Symeonidou IE, Nikolopoulou P, Lygerou Z and Taraviras S: Licensing of DNA replication, cancer, pluripotency and differentiation: An interlinked world? Semin Cell Dev Biol 30: 174-180, 2014.

34. Wong RS: Apoptosis in cancer: From pathogenesis to treatment. J Exp Clin Cancer Res 30: 87, 2011.

35. Orlando DA, Lin CY, Bernard A, Wang JY, Socolar JE, Iversen ES, Hartemink AJ and Haase SB: Global control of cell-cycle transcription by coupled CDK and network oscillators. Nature 453: 944-947, 2008.

36. Dang CV and Lewis BC: Role of oncogenic transcription factor c-Myc in cell cycle regulation, apoptosis and metabolism. J Biomed Sci 4: 269-278, 1997.

37. Sipos F, Firneisz G and Múzes G: Therapeutic aspects of c-MYC signaling in inflammatory and cancerous colonic diseases. World J Gastroenterol 22: 7938-7950, 2016.

38. Surget S, Khoury MP and Bourdon JC: Uncovering the role of p53 splice variants in human malignancy: A clinical perspective. Onco Targets Ther 7: 57-68, 2013.

39. Diehl JA: Cycling to cancer with cyclin D1. Cancer Biol Ther 1: 226-231, 2002.

40. Mohanty S, Mohanty A, Sandoval N, Tran T, Bedell V, Wu J, Scuto A, Murata-Collins J, Weisenburger DD, Ngo VN: Cyclin D1 depletion induces DNA damage in mantle cell lymphoma lines. Leuk Lymphoma 58: 676-688, 2017.

41. Zhou J, Li LU, Fang LI, Xie H, Yao W, Zhou X, Xiong Z, Wang LI, Li Z and Luo F: Quercetin reduces cyclin D1 activity and induces G1 phase arrest in HepG2 cells. Oncol Lett 12: 516-522, 2016.

42. Posternak V and Cole MD: Strategically targeting MYC in cancer. F1000Res 5: F1000, 2016.

43. Rajput S, Khera N, Guo Z, Hoog J, Li S and Ma CX: Inhibition of cyclin dependent kinase 9 by dinaciclib suppresses cyclin B1 expression and tumor growth in triple negative breast cancer. Oncotarget 7: 56864-56875, 2016.

44. Oleinik NV, Helke KL, Kistner-Griffin E, Krupenko NI and Krupenko SA: Rho GTPases RhoA and Racl mediate effects of dietary folate on metastatic potential of A549 cancer cells through the control of cofilin phosphorylation. J Biol Chem 289: 26383-26394, 2014.

45. Gastonguay A, Berg T, Hauser AD, Schuld N, Lorimer E and Williams CL: The role of Racl in the regulation of NF- $\kappa$ B activity, cell proliferation, and cell migration in non-small cell lung carcinoma. Cancer Biol Ther 13: 647-656, 2012.

46. McMahon SB: MYC and the control of apoptosis. Cold Spring Harb Perspect Med 4: a014407, 2014. 
47. Nikolova E, Mitev V, Minner F, Deroanne CF and Poumay Y: The inhibition of the expression of the small Rho GTPase Racl induces differentiation with no effect on cell proliferation in growing human adult keratinocytes. J Cell Biochem 103: 857-864, 2008.

48. Kalra N and Kumar V: c-Fos is a mediator of the c-myc-induced apoptotic signaling in serum-deprived hepatoma cells via the p38 mitogen-activated protein kinase pathway. J Biol Chem 279: 25313-25319, 2004

49. Parri M and Chiarugi P: Rac and Rho GTPases in cancer cell motility control. Cell Commun Signal 8: 23, 2010.

50. Sanz-Moreno V, Gadea G, Ahn J, Paterson H, Marra P, Pinner S, Sahai E and Marshall CJ: Rac activation and inactivation control plasticity of tumor cell movement. Cell 135: 510-523, 2008.

51. Vader P, van der Meel R, Symons MH, Fens MH, Pieters E, Wilschut KJ, Storm G, Jarzabek M, Gallagher WM, Schiffelers RM, et al: Examining the role of Rac1 in tumor angiogenesis and growth: A clinically relevant RNAi-mediated approach. Angiogenesis 14: 457-466, 2011.
52. Brantley-Sieders DM, Zhuang G, Vaught D, Freeman T, Hwang Y, Hicks D and Chen J: Host deficiency in Vav2/3 guanine nucleotide exchange factors impairs tumor growth, survival, and angiogenesis in vivo. Mol Cancer Res 7: 615-623, 2009.

53. Westermarck J and Kähäri VM: Regulation of matrix metalloproteinase expression in tumor invasion. FASEB J 13: 781-792, 1999.

54. Jin G, Sah RL, Li YS, Lotz M, Shyy JY and Chien S: Biomechanical regulation of matrix metalloproteinase-9 in cultured chondrocytes. J Orthop Res 18: 899-908, 2000.

55. Yang WH, Lan HY, Huang CH, Tai SK, Tzeng CH, Kao SY, Wu KJ, Hung MC and Yang MH: RACl activation mediates Twist1-induced cancer cell migration. Nat Cell Biol 14: 366-374, 2012.

This work is licensed under a Creative Commons Attribution-NonCommercial-NoDerivatives 4.0 International (CC BY-NC-ND 4.0) License. 